\title{
Augustine Ejikeme Ilodibe and the Development of Motor Vehicle Transport in Nigeria, 1955-2007: A Study in Indigenous Entrepreneurship
}

\author{
D. I. Ajaegbo, Ph.D \\ Department of History \& Strategic Studies, Federal University, Ndufu-Alike Ikwo, PMB 1010, Abakaliki, \\ Ebonyi State of Nigeria
}

\begin{abstract}
The Igbo who predominantly live in the south-east geo-political zone of Nigeria are very individualistic, enterprising, competitive and have a strong belief in a free market economy. The Igbo spirit of enterprise and initiative helped them not only to respond quickly to innovations introduced in Nigeria by the British colonial administration but also to accelerate the process of change and development which was already underway prior to British advent and colonial rule. Some of these innovations were the introduction of modern roads and motor vehicles. How Igbo individualism, entrepreneurial spirit and receptivity to innovations inspired one Ejikeme Ilodibe to invest in motor vehicle transport and revolutionize this novel enterprise was the focus of this paper. Ejikeme Ilodibe whose business name is Ekene Dili Chukwu represented a fascinating example of a Nigerian indigenous entrepreneur whose vision, capital, initiative, enterprising and innovative spirit contributed significantly to the commercialization of motor transport as a private sector industry in Nigeria.
\end{abstract}

Key words: indigenous, entrepreneur, commercialization, innovation, novel.

\section{Introduction}

The dynamics of change and development in Igboland, like other Nigerian societies, predated British advent and colonialism. There were certainly such endogenous forces or agents of change and development as long distance trade, warfare, technological innovations, occupational specialization and demographic shifts. For example, the knowledge of iron technology and production of iron implements by Awka, Agbaja-Udi, Abiriba and Nkwerre smiths facilitated the conquest of the environment and revolutionized agriculture, hunting and warfare. A well organised network of markets and trade routes which criss-crossed the Igbo country led to the development of a dynamic exchange economy, new bonds of relationships and flow of ideas and cultures (Nwabughuogu, 1993; Ajaegbo, 2010). Thus contrary to some Eurocentric writers (Mcphee, 1926; TrevorRoper, 1969; Smith, 1976) who saw pre-European African societies as stagnant, static and unchanging and attributed the dynamics of change and development to external factors, the process was already underway prior to British colonial rule. As Hopkins (1973) rightly pointed out, colonial rule did not create modernity out of backwardness. So when the colonial administration introduced such innovations as motor vehicles, modern roads, new currencies and new crops, some Nigerian peoples responded quickly and favourably to these economic stimuli.

The Igbo who predominantly live in the south-east geo-political zone of Nigeria are very individualistic, enterprising, achievement-oriented, competitive and have a strong belief in free market economy. The Igbo spirit of enterprise, innovativeness, initiative and individualism are potent factors which, to a considerable degree, account for the rapid pace of development in Igboland. How Igbo individualism, entrepreneurial spirit and receptivity to innovations inspired one Ilodibe to invest in and commercialize motor transport industry, in response to economic incentives and opportunities created by the British colonial administration, argue strongly and favourably for this paper.

\section{Early Life}

Chief Augustine Ejikeme Ilodibe, who was popularly known by his business name "Ekene Dili Chukwu", remains a household name in the transport history of Nigeria. He was born on $18^{\text {th }}$ December 1932 at Ndimgbu Otolo, Nnewi in Anambra State of Nigeria. In 1942, at the tender age of ten, he lost his father to death and the mother took him to Aba where he lived with his cousin and transport entrepreneur, Chief J.C. Ulasi. The tragic death of Chief Ulasi in 1945, barely three years Ilodibe was apprenticed to him, forced the young boy to return home to his mother. Traumatized by the death of her husband and the guardian and master of her son, Mrs. Eunice Ilodibe entrusted her little son to the custody and care of a catholic priest, Reverend Father (Fr) Louis Kettels. Fr. Kettels was the parish priest of Nnewi between 1942 and 1962 and during his 
long and dynamic apostolate, evangelization and educational development received tremendous impetus in the town (Metuh-Ikenga \& Ejizu, 1985). As a domestic servant to Fr. Kettels, Ilodibe seized the opportunity of Fr. Kettels dynamic educational scheme to receive his primary education at St. Joseph's Catholic Primary School, Okofia-Nnewi. In 1950, Ilodibe peacefully secured his freedom as a domestic help to Fr. Kettles. In appreciation of his humility, dedication to duty, honesty and sound moral character, the clergyman blessed and rewarded him with the sum of $£ 35$ (Forrest, 1995, Ilodibe, 2007).

With the $£ 35$ given to him by Fr. Kettels, Ejikeme Ilodibe wanted to venture into transport business but his little capital would not enable him to embark upon such a capital - intensive enterprise. Consequently, he decided to turn to motor spare parts trade. In the words of Ilodibe (2003: ix), "although, I started life as a dealer in motor spare parts, I had my eyes on motor transport business". To achieve mastery of the knowledge and skills necessary for the trade, he spent a few years as an apprentice to his maternal uncle, Chief D.C. Chukwujekwu, who was a successful dealer in motor spare parts. On successful completion of his apprenticeship, Ilodibe started his own business life as a trader in motor spare parts at Onitsha. As his business grew and expanded, his commercial activities took him from Onitsha to Lagos and as far as Gold Coast (now called Ghana). Endowed with immense entrepreneurial skills, he accumulated sufficient capital within a short period of time and his initial vision of carving out a niche for himself in the transport sector of the economy partly propelled him to enter into motor transport industry. Ilodibe was also inspired to venture into motor transport business by the successes of some Nnewi pioneer transport entrepreneurs like Chief J. C. Ulasi, Sir Louis Odumegwu Ojukwu, C. Egwuatu, D.C. Emefo and Albert Igbokwe. According to Ilodibe (2003:ix),

'Impressed by the success achieved by my late cousin and Master Chief J.C. Ulasi and inspired by other successful motor transport operators at the time like Chief D.C. Emefo, Sir Odumegwu Ojukwu and Mr. Albert Igbokwe, I began to nurse a strong ambition to become a transport magnate'.

After a few years of trading in motor spare parts, Ilodibe effectively and practically began motor transport operation and management in 1955. As a matter of fact, it was in 1955 that he bought his first Austin lorry from Societe Commerciale de l'Ouest Africain (SCOA). By November of the same year, he had purchased his second Austin lorry. In 1958, he bought his first most prized, amazingly rugged and highly demanded 911 Mercedes-Benz lorry from Armels Motors Ltd. He operated his transport business alongside his motor spare parts trade. The spectacular achievements he recorded in a short space of time and his realization that mechanical road transportation and management were time-consuming and required strong commitment to duty and meticulous supervision made him to wind up his "motor spare parts business so as to fully concentrate on road transport business" (Ilodibe, 2003: ix).

\section{Road Development, Emergence of Urban Centres and Indigenous Initiative as Facilitators of Motor Transport Revolution}

Prior to the establishment of colonial administration in Nigeria, road building had become a significant part of the people's socio-economic life. While most of the roads existed as foot-paths, a few were good and were well maintained. When A.G. Leonard, one of the military commanders who led British expeditionary forces into the hinterland of Igboland visited Bende in 1896, he saw "broad, well-kept, beautiful avenue of trees" (Isichei, 1977:213). Roads promoted trade as well as social interactions. However, the massive road construction programmes executed by the British colonial administration between 1900 and 1960, the introduction of motor vehicles and the emergence of new urban centres helped to create the conditions for commercialization of road transportation in the country. For example, by 1960, south-eastern Nigeria of which Igboland constituted the largest part, had a total of 14,026 miles of road out of which 1,060 were tarred, 27,000 vehicles were plying Nigerian roads while Enugu, Port-Harcourt, Aba, Onitsha, Owerri, Calabar, Benin City, Ibadan, Lagos, Kaduna, Jos, Kano etc. had emerged or expanded as prominent urban centres (Ekundare, 1973, Olanrewaju, 1987, Okoye, 1996 \& Njoku, 2001).

One major consequence of the rapid expansion of colonial infrastructure was that the Igbo, more than any other ethnic group in Nigeria, began to migrate to other parts of the country in increasing numbers in search of economic opportunities as traders, artisans, technicians, drivers, farmers and salaried or wage earners in the civil service or expatriate companies (Ajaegbo, 2010). As more economic opportunities were created, Chief Ilodibe responded to these economic stimuli by expanding his fleet of vehicles and opening up more routes to different parts of the country to meet the transport needs of the dynamic, enterprising and peripatetic Igbo elements. The expatriate firms like the United African Company (UAC), John Holt and SCOA also engaged the services of his vehicles in the movement and distribution of import and export commodities across the country. Thus, at the outbreak of the Biafra-Nigeria war in 1967, Chief Ilodibe had built up a huge fleet of fifty-four vehicles, consisting of lorries, buses and peugeot station wagon cars (Forrest, 1995). 
The Biafra-Nigeria war began in 1967 and ended in 1970. Chief Ilodibe, like other Nigerian businessmen, suffered a serious setback following the outbreak of hostilities. In fleeing to the east for his dear life, Ilodibe abandoned many of his vehicles in different parts of the country especially in the North and West. During the war, he was the head of the Directorate of Transport in the defunct Republic of Biafra and donated his vehicles towards the war efforts. He lost a great number of these vehicles in the course of the war and the few that remained had deteriorated so gravely that at the cessation of hostilities in 1970, his transport industry lay in ruins. To revive it, Ilodibe (2007:4) noted that Chief A.E. Ilodibe "sold his only personal Mercedes Benz Car that survived the civil war at a price of 400.00 pounds [£400] to assist him acquire two 911 Mercedes Benz lorries on Hire Purchase from Leventis Motors Ltd". With these two lorries, he began to recover fast from the reverses of the civil war. By 1973, he had sufficiently recovered from his losses that he formally incorporated his transport company as Ekene Dili Chukwu (Nigeria) Ltd, meaning Thanks Be To God.

Chief Ilodibe was a leading figure in the innovations and commercialization which characterized motor transport enterprise before and after the civil war. Prior to the outbreak of the war, one of the innovations he helped to expand in motor transport industry was to purchase Morris, Austin and Mercedes-Benz 328 chassis and construct them into tinker buses and wooden lorries. The wooden lorries and tinker buses were both used for road freight and passenger transport services. Some of these vehicles had three compartments categorized into first, second and third class cabins and fares were charged in the same order. The first and second class cabins were the favourites of wealthy and middle class passengers. The lorries were used to carry goods, passengers or both. According to Ilodibe (2003:7) "economic consideration, availability of goods and passengers and profitability guided the owners and the drivers of the lorries in making the choice of either carrying goods or passengers or both".

The introduction of luxury bus services was a post-civil war phenomenon. At the end of the war, the government of East Central State established a transport company called the Oriental Line. The Oriental Line was a unit of the civil service establishment and was therefore operated as a public enterprise rather than a commercial concern (Esse, 2005). The company was primarily established to alleviate the transport problems of Igbo people whose communities and means of livelihood were devastated during the war. In spite of government active involvement in this enterprise, the Oriental Line soon collapsed and folded up owing largely to the sharp practices of the drivers and their mates, management inefficiency and bureaucratic controls, shortage of spare parts and the terrible condition of the roads.

The poor performance of Oriental Line and its concomitant collapse created a gap which Igbo private road transporters were to fill. Leading the way in this commercial enterprise was Chief Ilodibe who as early as 1972 introduced inter-city and intra-city transport bus services using 508D and 608D Mercedes-Benz models. Basking in the profitable and excellent performance of these medium-sized Mercedes-Benz models and exploiting the demise of Oriental Line in 1974, Chief Ilodibe launched the Mercedes-Benz 0362 luxury bus services the same year and thus became the first Igbo private motor transport entrepreneur to do so. Between 1974 and 1979, he introduced and popularized the use of Mercedes-Benz 0362 and 0364 models for luxury bus operations in Nigeria and this innovation in the words of Ilodibe (2003:9) "marked the beginning of real luxury bus business in Nigeria".

Ilodibe's trail-blazing innovation was successful and revolutionary in some important respects. First, it inspired and influenced other Igbo motor transport entrepreneurs and some state governments to venture into luxury bus and road freight or haulage. Among the Igbo, the most notable were Chief P.N. Emerah, Managing Director (MD), P.N. Emerah and Sons (Nig) Ltd, D.C. Ubajaka, MD, Izuchukwu Transport (Nig) Ltd, Chidi Anyaegbu, MD, Chisco Transport (Nig) Ltd, Eugene Ojukwu, MD, E. Ekeson Transport Services, Frank Nneji, MD, ABC Transport, among others. Some state governments like Bendel and Benue states also engaged in inter-state luxury bus operations. Second, as more entrepreneurs entered luxury bus and road haulage inter-state services, the scope of transport businesses expanded and widened to cover prominent urban centres across the country such as Owerri, Aba, Lagos, Port Harcourt, Onitsha, Kano, Kaduna, Ibadan, Jos, Maiduguri and Enugu. An unprecedented surge in the movement of traders, businessmen, civil servants, goods and services as well as opening up of business enterprises across the country also developed. It is instructive that the massive movement of people through luxury bus services facilitated and quickened the re-integration of the Igbo into other parts of the country at the end of the civil war. Third, Ilodibe established powerful and enduring commercial contacts with Leventis Group - a leading distributor of Mercedes Benz products - as well as Daimler-Benz AG/Mercedes-Benz AG and Mercedes Do Brazil respectively. This commercial relationship helped him to distribute and popularize the use of various models of Mercedes-Benz luxury buses, lorries, tankers and trailers for intra and inter-state services in Nigeria. As a leader in the use of Mercedes-Benz motor vehicles in passenger transport and road haulage operations in Nigeria, Ekene Dili Chukwu Ltd became an authorized dealer and distributor of Mercedes-Benz vehicles and spare parts in Nigeria for Leventis Group of Nigeria, Daimler-Benz AG Stuggart of West Germany, Mercedes-Benz Do Brasil of Brazil and MB Anammco (Nig) Ltd of Enugu, Nigeria. Fourth, the company pioneered the construction of private parks in the transport 
industry in Igboland and perhaps in the country as a whole. The company built its own parks at Onitsha, Lagos, Enugu, Kaduna and Abuja. Some of these parks have lodging and restaurant facilities as well as well-equipped maintenance workshops.

Another innovation of Chief Ilodibe which was of great revolutionary importance was in the sphere of motor transport ownership and management. Sole proprietorship remained a dominant feature of motor transport industry since its inception in the 1920s. Notwithstanding the advantages of prompt internal capital mobilization, quick decision making and effective supervision, sole responsibility for risk-taking and strong family or kinship involvement which sole proprietorship enjoys, this type of business organisation often operates without an office, office equipment or trained personnel. In some cases, it folds up with the incapacitation or death of the founder. Owing to strong family involvement in a single ownership company, the death of the founder sometimes precipitates a legal tussle over the control of the business organisation. To obviate these problems, Ilodibe set up a well organised transport company with an elaborate administrative machinery. The company had a board of directors, a chairman/chief executive officer, a general manager and audit, legal, accounting, purchasing, maintenance, public relations units, among others. A good number of its personnel were well-educated and all categories of staff underwent training and re-training within and outside the company, from time to time. The establishment of an elaborate and functional transport business organisation characterized by efficient management mechanism largely accounts for the continued existence and operation of Ekene Dili Chukwu (Nigeria) Limited to this day.

The triumph of Chief Augustine Ejikeme Ilodibe, not only as the Managing Director/Chief Executive Officer of Ekene Dili Chukwu Transport (Nig) Limited but also as a private indigenous motor transport entrepreneur was not without risks and challenges. His company encountered the problems of capital scarcity, poor state of Nigerian roads, vehicular accidents, high purchasing, operating and maintenance costs, staff indiscipline, menace of highway armed robbers, reverses of the civil war, government economic policies and cut-throat competition among transport operators. Ilodibe's initiative, enterprising spirit and efficient management of human and material resources were potent factors which helped him to successfully weather the vicissitudes of motor road transportation for over forty-five years.

The huge successes recorded by Chief Ilodibe in the road transport industry provided him with the necessary experience and capital which enabled him to diversify into transport related and non-transport economic enterprises. He built a conglomerate known as Ekene Dili Chukwu Group which consisted of the following companies (Ilodibe, 2007; Forrest, 1995).

(a) Ekene Dili Chukwu (Nig) Limited which provides bus, taxi and road haulage services.

(b) Ekene Dili Chukwu Motors which imports Mercedes Benz spare parts. It also undertakes maintenance services in its many workshops located at Onitsha, Enugu, Owerri, Kaduna, Jos, Benin, Lagos and Abuja.

(c) Ekene Dili Chukwu (steel structures) Limited. In partnership with Emil Doll KG of Germany, it is engaged in steel and aluminum fabrication, construction of vehicle bodies such as trailers, tankers, bullion vans, refusal disposal and fire fighting equipments.

(d) United Modern Issurance Brokers Limited handles insurance services.

(e) Austin Farms and Allied Industries Limited. This is an integrated farm located at Anaku in Ayamelum Local Government Area of Anambra State. It produces livestock feeds and has piggery, poultry, cassava and rice farms.

(f) Austin Ejikeme Properties Limited is a real estate acquisition and development enterprise.

(g) Speedmark Services Limited is a courier service company.

A man of great vision, industry, humility and philanthropic spirit, Chief Ilodibe used his vast wealth in community development efforts and for the improvement of the living conditions of people within and outside Nnewi community. His business empire offered jobs to many Nnewi indigenes and individuals of non-Igbo origins and instituted a scholarship programme which provided opportunity for many less privileged Nnewi sons and daughters to acquire education. Other philanthropic activities included the building of a one storey building named after Rev. Fr. Kettel at St. Joseph's Catholic Church, Okofia-Nnewi, donation of five million ( $\$ 5 \mathrm{~m}$ ) naira towards the building of College of Medical Sciences of Nnamdi Azikiwe Teaching Hospital, Nnewi, and construction of School of Post-Graduate Studies and a guest house for the University of Nigeria, Nsukka, among others.

It is instructive that Ilodibe's wealth of experience accumulated in road transport enterprise for over four decades equipped him with the knowledge and skill to write a trail-brazing book entitled: Road Transport Management in Nigeria. This pioneering work is a conspectus of the rudiments and strategies of successful motor road transport acquisition, operation, management and technology in Nigeria. The author makes a detailed analysis of the difficulties and practical challenges of road transport enterprise. It also proffers solutions to these problems. The book is a very important resource material for road transport operators as well as teachers and students of transport studies. 
As a pathfinder in road transport industry in Nigeria and in recognition of his many contributions to national development, Ilodibe was given many appointments, awards, titles and honours. For example, the Federal Government appointed him a member of the Federal Urban Mass Transit Programme (FUMTP), Petroleum Prices, Supply and Distribution Committee (PPSDC) and Committee on Export Processing Zone (EPZ). In 1988, the universities of Ilorin and Nigeria, Nsukka awarded him Doctor of Science (D.Sc) and Doctor of Business Administration (DBA) respectively. In 2000 he was also conferred with the national honour of Member of the Federal Republic of Nigeria (MFR). He was also the first Nigerian to become a Fellow of the Institute of Transport Administration of the United Kingdom (F.Inst.TA(UK). His public-spirited and humanitarian development efforts earned him a host of traditional titles prominent of which was Onwa n'etilioha of Nnewi, meaning the moon that shines for all and sundry.

\section{Conclusion}

The advent of motor transport vehicles and the construction of modern roads were some of the innovations introduced by the British colonial administration in Nigeria. These novel economic incentives and opportunities were embraced and exploited by Nigeria private entrepreneurs. Ilodibe represented a fascinating example of an indigenous entrepreneur whose vision, capital, business acumen and innovations placed him head and shoulders above other transport operators in the commercialization of vehicular transport industry in Nigeria. Though he passed away on Sunday, the first day of July, 2007, the solid foundation he laid for his transport industry and the legacy of professional and efficient management of men and resources have kept the company alive and afloat to date. He grasped the new opportunities created by colonial administration in mechanical road transportation, took key entrepreneurial decisions and risks and also introduced fundamental changes in this vital sector of the Nigerian economy. Chief Augustine Ejikeme Ilodibe's initiative, skills, energies and enterprising spirit are useful lessons which our present and future transport entrepreneurs should learn from this transport mogul.

\section{References}

[1]. Ajaegbo, D.I. (2010). Nnewi of north-western Igboland: A study of an Igbo society in transition, 1905-1999. Unpublished Ph.D Thesis, Department of History \& International Studies, University of Nigeria, Nsukka.

[2]. Ekundare, R.O. (1973). An economic history of Nigeria, 1860-1960. London: Methuen \& Co. Ltd.

[3]. Esse, U. (2005). Road transport in Nigeria as a private enterprise among the Igbo, 1920-1999. Unpublished Ph.D Thesis, Department of History, University of Nigeria, Nsukka.

[4]. Forrest, T. (1995). The makers and making of Nigerian private enterprise. Ibadan: Spectrum Books Limited

[5]. Hopkins, A.G. (1973). An economic history of West Africa. London: Longman Group Ltd.

[6]. Ilodibe, A.E. (2003). Road transport management in Nigeria. Lagos: Impo Associates.

[7]. Ilodibe, M. (2007). Order of service for the burial of late dr chief Augustine Ejikeme Ilodibe, 1932-2007. Lagos: Impo Associates.

[8]. Leonard, A.G. (1896). Notes of a journey to Bende in Isichei, E. (ed) Igbo worlds. London: Macmillan.

[9]. Mcphee, A. (1926). The economic revolution in British West Africa. Africa. London: Routledge.

[10]. Metuh-Ikenga, E. \& Ejizu, C.I. (1985). Hundred years of catholicism in eastern Nigeria: 1885-1985. The Nnewi story. Nimo: Asele Institute.

[11]. Nwabughuogu, A.I. (1993). The dynamics of change in eastern Nigeria, 1900-1960: Indigenous factor in colonial development Owerri: Esther Thompson Publishing company.

[12]. Njoku, O.N. (2001). Economic history of Nigeria. Enugu: Magnet Business Enterprises

[13]. Okoye, T.O. (1996). The city in south-eastern Nigeria. Onitsha: University Publishing Company.

[14]. Olanrewaju, S.O. (1987). The infrastructure of exploitation: Transport, monetary changes, banking, etc in T. Falola (Ed). Britain and Nigeria: Exploitation or development. London: Zed Books Ltd.

[15]. Smith, D.E. (1974). Religion, politics and social change in the third world. New York: The Free Press.

[16]. Trevor-Roper, H. (1969). The past and the present: History and sociology. Past \& Present, 42. 